\title{
Will It Be Possible for Artificial Intelligence Robots to Acquire Free Will and Believe in God?
}

\section{Yapay Zekâ Robotlarının Bir Gün Özgür İrade Edinip Tanri'ya Inanmaları Mümkün Olacak m??}

\section{MUSTAFA ÇEVİK}

Social Sciences University of Ankara

\author{
Received: 06.12.2017 | Accepted: 28.12.2017
}

\begin{abstract}
This essay deals with the subject of whether artificial intelligence robots will gain consciousness in the future. The general perception of artificial intelligence robots and then the validity and rationality of this perception will be discussed. This is followed by a comparison between the structure of preprogrammed artificial intelligence robots and the structure of things in the nature. Then comes their comparison to human beings with regard to emotions, free will and ability to make a choice, and a discussion of their similarity to angels. Finally, the study will in detail deliberate over why artificial intelligence robots will not be able to have free will.
\end{abstract}

Keywords: Artificial intelligence, robotics, free will, mechanism, angel, will, personality.

(C) Çevik, M. (2017). Will It Be Possible for Artificial Intelligence Robots to Acquire Free Will and Believe in God? Beytulhikme An International Fournal of Philosophy, 7 (2), 75-87. 
There is a lot of exaggerated and implausible talk about robots these days. They are portrayed in such a way that they are made to look like a more advanced form of humans, which will displace and dominate human beings. You can hear a scientist, a thinker, a clergyman or a politician speaking in that way. There are a host of issues that such people cannot take in and deal with. In order for robots to rule human beings, they will need to possess the autonomy to take decisions by themselves.

They should be able to make their own choice consciously and take initiative. And for all these, they should have "free will". Have those who claim that robots will have the ability to decide by themselves, rule people and thus will replace them pondered over these issues seriously? Of course, not. Proponents of this position do not base their ideas on concrete information. This is just what they wish for technology and artificial intelligence robots to be like in the future. This study aims to shed light on the validity of such claims.

We will not do so by examining robots in the laboratory. Actually, it is not possible to examine robots in such a way. Instead, we will try to reveal that robots will not be able to act on their own initiative, basing our argument on the inconsistencies of such talks about robots and robotics. That's why we asked the ironic question "Will it possible for robots to believe in God?"in the title of the essay. If the predictions made about the acquisition of free will by robots prove to be true, then it follows from this that they may prefer to believe in God.

In fact, this question could be asked in many different ways: Can robots teach themselves? Can they think? Can they cry? Can they laugh? Can they have emotions? What all these questions have in common is the question of whether free will is within the scope of robots.

So, what do people try to mean by these questions? What is the philosophical question here? As is known, philosophy aims to deal with not secondary issues but the real problem causing them. Then, what is the essential problem here? We propose that the real question to be asked is whether robots can do something other than they are instructed to do or whether they can make a choice by themselves. All other questions mentioned above are only of secondary importance. 
Why is this question so important then? This question is raised as a subject of discussion because of the dangers or threats likely to be posed by artificial intelligence robots in the event of their acting on their own accord. What makes this question so important is the fact that humanity will face a very serious disaster in such a situation. Yet, this question does not concern us here. What concerns us is a philosophical-theological question. What basically distinguishes a person from any other thing is the fact that man's choice is made consciously and voluntarily and that a thing's movement is not based on a choice. Then, are a robot's actions similar to man's voluntary actions or to a thing's involuntary actions? Actually, all things, living or non-living,act the way they are programmed to do. When the conditions required by their programmers are met, the action expected or anticipated always occurs, which is also the case with artificial intelligence robots. Man is the only exception. Man does not act as a programmed being. He can make choices of his own accord, without being restricted by programming. Although it is possible for him to act otherwise, he makes a choice of his own and does it in the way he chooses. There is a verse in the Quran which seems to address this issue.

"Just think, when your Lord said to the angels: "Lo! I am about to place a successor on earth," they said: "Will You place on it one who will spread mischief and shed blood while we celebrate Your glory and extol Your holiness?" He said: "Surely I know what you do not know." Then Allah taught Adam the names of all things and presented them to the angels and said: "If you are right (that the appointment of a successor will cause mischief) then tell Me the names of these things." They said. "Glory to You! We have no knowledge except what You have given us. You, only You, are All-Knowing, All-Wise.” (Baqarah/30-32)

Who is "the successor" mentioned in these verses? This is a subject of debate among theologians. Whether he is a prophet named Adam or represents the whole humanity is debatable. What concerns us here is the following excerpt from verse "We have no knowledge except what You have given us." This is actually an acknowledgement by angels that humans are superior to them. They revere this new species as the "successor" of God. What aspect of Adam makes him superior to angels? The fact that he is more knowledgeable seems to put him at the forefront of 
angels. Yet, the important point is that this praise does not stem only from his being more knowledgeable. We can infer the essential divergence between the two species from what angels say. The real difference between angels and Adam is related to the source of knowledge rather than its quantity. While for the former knowledge is something taught, for the latter it is something that can be increased, and something new that can be deduced from what has been taught. Angels' knowledge is limited to "only knowing what has been taught to them." It seems that man's knowledge is not limited to "only knowing what has been taught to him."

Man has some knowledge like all living things. Every living being has some knowledge peculiar to itself, a kind of defense system and a means of communication within its own species. Although species evolve biologically, their own form of knowledge does not seem to change to a large extent. What I mean here is not a biological process but a cognitive one. I refer to consciousness, mind and soul. Man's state of consciousness, mind and intelligence is not limited to "only knowing what has been taught to him" as in the case of the angels mentioned in the verses above. Man differs from angels in this respect. Unlike angels and animals, he possesses a cognitive and mental capacity to increase, transform and disseminate knowledge taught to him.

Yet, is it possible to suggest that man's state of mind and consciousness can also be regarded as a kind of instinct like some knowledge possessed by animals instinctively. This is what David Hume proposes. Hume says, "Reason is nothing but a wonderful and unintelligible instinct in our souls." (Hume: 179)

What is instinct then? What I am searching here is not the source of instinct, because searching its source is actually to ask how it has been put into living things. When living things acquired it can be explained by either evolution or creation. That's why, I would like to focus on what it is rather than the source of it. Although man also acts instinctively to a certain extent, he generally acts using his free will and choices. For the time being, we had better reserve instinct for animals. Instinct is the animals' manifestation of the same behaviors when they are activated by stimulants in certain situations. Animals always manifest behaviors pecu- 
liar to their own species in certain cases and when certain stimulants exist. These behaviors are of a certain structure, innate, not learned and peculiar to a species. (see, Ryan-Deci: 28-30) According to von Uexküll, "animals possess not only a mechanic structure but also operators placed within their organs. Therefore, we now see animals not as simple machines but things whose basic actions consist of perception and application." (von Uexküll:6)

It seems that "instinct" is actually an innate trait. Though most biologists, as von Uexküll suggests, say that animals are different from machines, we can easily accept that "instinct" is decisive in animal behavior. If animals have made a different planning or choice from their own species, there could be a diversification in their behaviors. In other words, animals do not have the power to choose or freedom contrary to the guidance of their instincts. In Islamic thought angels are similarly regarded as beings with no will and those who do what they are ordered to do. Moreover, not only angels but also the whole physical world act in the direction of their nature. This is expressed in various parts of theQuran (al-Hajj, 22/I8; ar-Rahman, 55/6). Though some contrary opinions, most of the Islamic scholars agree that angels act in accordance with their nature as do all other beings. A being's acting in accordance with its nature means being limited by one's own nature.

Like every being, whether living or non-living, in the universe angels also exist without a partial free-will. In other words, angels, like other biological and physical things, do only what "they are taught to do". Let's consider the complicated internal structure of a live cell and its functioning. A cell only does what "it is instructed to do", nothing else. Functioning of robots can also be likened to that of cells, because they also act as they are programmed to do. Thus, our evaluation concerning cells' functioning is also the case with that of robots. They cannot attempt to do anything contrary to what they are programmed to do.

If robots do not have free-will, then it follows that they cannot laugh, believe and love and so on.

\section{Why Cannot a Robot Think?}

Thinking, believing, laughing and feeling are humanly activities. A 
robot's having humanly feelings means its being a human, as Hamilton says (Hamilton, 57). In I950, Alain Turing claimed that machines could speak. When asked "can machines think?", he replies, "I believe it is too meaningless to deserve discussion. Nevertheless, I believe that at the end of the century the use of words and general educated opinion will have altered so much that one will be able to speak of machines thinking without expecting to be contradicted."(Turing: 433-460)

Turing's foresightedness certainly deserves appreciation. Although it is possible for computers to speak, this can only be within "the instructed" framework. Otherwise, this means getting out of the program imposed on them. Let's assume that this robot acts on its own accord. If this is the case,

I- It cannot be understood according to what criteria the robot makes a choice. In such a case, this can be either a malfunction or coincidence. Yet, if this is a coincidence, there should be a logic to it, because this neither a preference nor an initiative. Humans have certain rational and emotional justifications while using an initiative. This justification can sometimes be systemic or limited to a single selection. But each is preferred for a reason.

2- If the robot's preference can be anticipated, then it means that this is a programmed and, therefore, an expected action. In each x case, $y$ should be chosen. That's why the robot makes the choice y. In such a situation, it cannot be said that the robot took initiative.

Saying that robots take initiative means saying that they have free will. As is known, there are lots of thinkers who claim that man does not have free will. It is difficult to argue that robots have free will while it is debatable whether man has free will. As Searle puts forward, "The first thing to notice about our conception of human freedom is that it is essentially tied to consciousness. We only attribute freedom to conscious beings. If, for example, somebody built a robot which we believed to be totally unconscious, we would never feel any inclination to call it free. Even if we found its behaviour random and unpredictable, we would not say that it was acting freely in the sense that we think of ourselves as acting freely." (Searle: I2O) 
Free will necessitates creating a process. Actually, a robot itself is in the making. If a robot creates a process after a certain stage, then it follows that it humanizes. In such a situation, robots would have to assume ethical and legal responsibilities, because they would make choices freely.

In an article titled "When robots have feelings" in the Guardian, Peter Singer and Agata Sagan say "If, as seems likely, we develop superintelligent machines, their right will need protection, too" (the Guardian, Dec I2, 2009). If robots has feelings, what they would do, as we have mentioned above, would be a free and conscious choice. Actually, what makes a choice a free action is the fact that they would choose not to do it. That they choose to do it makes this action free. In such a situation, two things need to be protected: a robot's right to choose and, thereby, its ethical and legal responsibilities.

God, state and society all hold humans responsible for such a preference made freely. But the underlying reason behind holding agents responsible for what they do is the acceptance that this choice is made by means of free will. If robots were to make free choices because of their feelings or others reasons, then it would follow that they have been arranged in such a way that their owner could not intervene in what they do. The reason behind why God holds man but not angels, animals or physical beings responsible is "the right to make a choice" bestowed to him.

At this point, robots will be accepted either as human-like machines feeling, getting worried and making free choices or as beings that have to make do with what they are given or are taught to do as iis the case with angels. While they will be free in the former case, they will be kind of programmed or pre-determined in the latter one.

Therefore, it can be easily said that even if a robot made a conscious choice, we could not determine its state of consciousness (Singer-Sagan, ibid). This is because today even man's state of consciousness cannot be understood much. In scientific studies, there is nothing surpassing guesses based on observation

A newspaper article with a similar topic appeared in the Independent on Feb 24th, 20I7, whose title was: "Robots and Al could soon have 
feelings, hopes and rights..." The essay's subtitle contains the following catchy question: "Could we see a future where AI could get married and do other things that people can?" The article mentions the procedure about getting legal permission to use artificial intelligence robots in public service. Robots are referred to as "robots personhood" in the legal regulation bill. It is this part of the article that concerns us. Discussing "personality" of robots generates an argument over "personal rights" automatically. Yet, what makes an entity "a person" is not rationality but free will (Frankfurt: II).

Basing on this maxim of Harry Frankurt, Peter Baumann lays down three conditions for accepting an entity as "a person":

(I) Cognitive abilities in broad sense: thought, intentionality, rationality (to some degree) and language; (2) self-consciousness and critical selfevaluation; (3) freedom and autonomy (to some degree). (Baumann: 4)

Jointly considering what they are proposing, it seems what they share in this respect is "autonomy." Similarly, Mary Anne Warren proposes five conditions for an entity to count as "a person":

(I) Consciousness (of objects and events external and/or internal to the being), and in particular the capacity to feel pain; (2) reasoning (the developed capacity to solve new and relatively complex problems); (3) selfmotivated activity (activity which is relatively independent of either genetic or direct external control); (4) the capacity to communicate, by whatever means, messages of an indefinite variety of types, that is, not just with an indefinite number of possible contents, but on indefinitely many possible topics; (5) the presence of self-concepts, and selfawareness, either individual or racial, or both. (Warren: 3)

At this point, a difference between man and other entities emerges. While humans have such a free will that they can act autonomously, actions of other entities "are limited by their nature." Only being other than God who has autonomy is man and thus only man is held accountable ethically.

Having free will is not obeying rules but violating them by choice, that is, on purpose or obeying them consciously. In order for robots to have free will, their producers should make robots disobeying rules, not 
robots obeying them. In other words, they should make robots that can take decisions on their own, for obeying rules requires mechanics but disobeying rules necessitates intelligence.

Biological aspect of humans can be likened to robots living in line with rules. Yet, people's aspect of consciousness and free will, which we call "person", seems to be totally different from robots and biological aspects. A human that we call a person has enough free will to act autonomously whereas other entities act "under the constraint of their nature."

For a robot's action to count as "a choice", first of all it has to be chosen with the aim of being beneficial or harmful. Secondly, the choice has to be independent of the robot's maker. For a robot's action to count as a conscious, disobedient choice and violation, it should, as P.Sullins suggests, be independent of the user (Sullins:24). A robot's action can count as a choice only when it acts differently from what it has been instructed to do. This means transforming an installed program. The problem here is not whether it has feelings or not. The problem is the disobedience of the robot to the person who has made it, which converts it from a machine to a human being.

The fact that angels cannot do anything contrary to what they have been instructed to do can be likened to the state of Robots. This is because robots and, generally speaking, machines cannot go beyond the design of those who create them as they do not have free will. As we mentioned above, not only angels but also but also all objects, animals and plants similarly operate "as they are taught to do" without making a choice. Therefore, they are not held ethically responsible in any religious or philosophical system, because ethical responsibility necessitates making free will.

Contrary to Daniel Dennet's claim that robots will one day have free will, Selmer Bringsjord argues that they will never have an autonomous will apart from their programmed nature (Brinsjord:20o8). As Haselager states, robots may be doing some tasks independently, but it is still a human, a programmer that establishes a goal despite that fact that choices depend on goals (Haselager: 519). No entity can set its own purpose of existence. There can be no choice about existing before existing. Humans can exceptionally have free will after existing. As we have mentioned 
above, entities without free will can neither decide on their existence in the beginning nor intervene in their existence process. All things whether stone or soil or water or air and so on continue their existence in the way they are programmed to do. As biological and technological entities are made up of these materials, neither their cellular internal structure nor their general structure is free from this mechanism. The logic of this mechanism is so simple. All entities that cannot make a choice by themselves, whether it be living or non-living, act in the direction of decisions made for them before or at that time. This is also the case with robots. They cannot make decisions by themselves, because they have no freedom to choose and never will they do. They only act within the logic pattern created by their programmers for them.

Sometimes you can hear such news: A robot developed in the $\mathrm{x}$ university makes sense of reactions by humans. For example, it can gather from the expression on the speaker's face whether he is happy or sad. Basing on this news item, some claim that robots will feel in the same way as humans one day in the future. There is some confusion here. Sensation is confused with using sensors. Sensor is a kind of technological sensitivity, which is actually nothing but a refined form of mechanics. It is a kind of internal mechanism or the one that cannot be seen by the eye. Yet, in a logical context face reading is no different from a mechanical interpretation, because in both of the cases there is an action and a reaction. When an $\mathrm{x}$ shaped face is introduced to the robot as happiness and $\mathrm{y}$ shaped face as unhappiness, it will not be difficult for the robot to discern what kind of "sign" the speaker makes by looking at this person's face. Yet, the robot will not know when the person facing it pretends to be happy. Of course, this cannot be discerned by "a human", either, because the state of the soul is not the same as that of the body. It is only a state of meaning.

It would be naïve to assume that robots will have free will and autonomy in the future by basing this on the fact that a video game or toy can make different moves in the absence of a player. This is because the operation of a robot is ultimately a matter of programming however detailed a calculation it makes. It carries out what the program installed by its producer orders it to do. The fact that it works too much, that it per- 
forms complicated tasks and that it calculates a vast range of possibilities all have to do with the fact that it processes data very rapidly and in a very sophisticated way. What distinguishes it from classical mechanics is its working in the magnetic field very rapidly. Yet, the logic behind its operations remains the same: It is not but a calculation of "If $x$ then $y$ ", "if $\mathrm{x} 2$ then $\mathrm{y} 2 . "$

As mentioned above, claiming that a robot now acts like "a human being" necessitates the robot's making a free and unexpected choice, going out of the frame imposed by its programmer. Free choices a robot makes whether arbitrarily or because of a peculiar reason or without a motive is what makes an entity a human.

So it can be said that robots will never have the faculty of thinking, because they have neither free will nor the ability to make a choice. They are programmed entities. Living and living things are also programmed. Both of them act according to an internal mechanism installed within them. Then, there are two types of entities in existence: Those acting according to a mechanism and those acting without a mechanism. And those acting according to a mechanism are also divided into two categories: those acting according "an external mechanism" and those acting according to "an internal mechanism." The outer surface of all mechanical entities is subject to the rules of "the external mechanism." Similarly, inner structure of mechanical entities is subject to "the internal mechanism." For example, the outer structure of a stone is supplanted by external mechanical effects. This mechanical movement is visible to the naked eye. However, its internal structure is replaced by an invisible "internal structure." Although it is invisible to the naked eye, it can be seen in the digital milieu or laboratory environment. But the difference between them is not "in essence" but "in degree." The difference in degree is that of refinement or coarseness.

It is also the case with robots whose external structure is activated by a physical and visible cause, which is the state of "external mechanism." Its internal structure, on the other hand, is "an internal mechanism" running by means of "a program language."

In "the universe" there are also entities not acting according a mechanism. These are animals and humans, whose behaviors are the same 
within their species. Yet, it is still difficult to predict behaviors of animals and humans beforehand. The unpredictability is particularly true of humans rather than of animals. Humans act instinctively to a large extent. This instinctive behavior may be likened to a kind of "internal mechanism." Still, we cannot say with certainty that all animals instinctively do action " $y$ " in situation " $\mathrm{x}$ ".

When it comes to man, the issue turns out to be more complicated. Man's physical world, that is to say, bodily structure is subject to a kind of mechanical structure of biology. His outer body is subject to "external mechanism" while his inner body is governed by "internal mechanism" like cellular structure. However, man's inner world is not governed by a "mechanism", whether internal or external.

What happens in man's mental and spiritual world is shaped according to the free will of a "person." Free will consciousness may change from person to person. A person may make a choice under the effect of a "social manipulation" though he thinks that he acts freely. Yet, it is still a freely made choice. The person is free when he performs it and is not dependent on a "mechanism".

Thus, it can be said that robots will never be able to act like humans, because they must be a "person" to be able to accomplish it. And to be able to be a person they should meet the conditions mentioned above. The main difference between humans and robots is an ontological one, not a developmental or evolutionary one. Therefore, it is not possible for robots to believe in or deny God, because they have no autonomy to make a choice of their own accord. As free will is something impossible on the part of robots, such expectations from robots are nothing but a kind of wishful thinking.

\section{References}

Baumann, P. (2007). Person, Human Beings and Respect. Polish fournal of Philosophy, 2, 5-17.

Bringsjord, S. (2008). Ethical Robots: The Future Can Heed Us. AI and Society, 22 (4), 539-550.

Deci, E. \& Ryan, R. M. (1985). Intrinsic Motivation and Self-Determination in Human Behavior. New York: Plenum Press. 
Frankfurt, H. G. (I97I). Freedom of the Will and the Concept of a Person. The Fournal of Philosophy, 68 (I), 5-20.

Hamilton, C. (20I4). On the Possibility of Robots Having Emotions. PhD Thesis. Georgia: State University.

Haselager, W. F. G. (2005). Robotics, Philosophy and the Problems of Autonomy. Pragmatics \& Cognition, $\mathrm{I} 3$ (3), 515-532.

Hume, D. (1978). Treatise of Human Nature (ed. L. A. Selby-Bigge). Oxford: Clarendon Press.

Markou, C. (20I7). Robots and AI could Soon Have Feelings, Hopes and Rights... We Must Prepare for the Reckoning. Independent, 24 February.

Searle, J. (2009). Akıllar, Beyinler ve Bilim (çev. K. Bek). İstanbul: Say Yayınları.

Singer, P. \& Sagan, A. (2009). When Robots Have Feelings. The Guardian, I2 December.

Sullins, J. P. (2006). When Is a Robot a Moral Agent? International Review of Information Ethics, 6, 23-30.

Turing, A. M. (1950). Computing Machinery and Intelligence. Mind, 59, 433-460.

Von Uexküll, J. (1957). A Stroll Through the Worlds of Animals and Men: A Picture Book of Invisible Worlds. Semiotica, 89 (4), 319-39I.

Warren, M. A. (1996). On the Moral and Legal Status of Abortion. Biomedical Ethics (eds. T. A. Mappes \& D. De Grazia). New York: McGraw-Hill, Inc.

Öz: Bu yazı yapay zekâ robotlarının kendiliğinden gelecekte bilinç ve özgür irade edinip edinemeyeceklerini ele almaktadır. Yapay zekâ hakkındaki genel algı ve bu algının geçerliliği ve rasyonel değeri de tartıșılacaktır. Ardından önceden programlanmıș yapay zeka robotlarının yapısı ile doğadaki varlıkların yapısı arasında karșılaștırma yapılacaktır. Yapay zekâ robotlarının duygu, özgür irade ve seçim konusunda insan ile karșılaștırılması yapıldıktan sonra meleklerin robotlar ile olan benzerlikleri ele alınacaktır. Son olarak da robotların özgür irade kullanamayacaklarının gerekçeleri üzerinde durulacaktır.

Anahtar Kelimeler: Yapay zekâ, robotlar, özgür irade, mekanizm, melek, kișilik. 